Aleksandra Naróg

\title{
Ekstaza i "nicość egzystencji”. O obrazach cielesności i jej barwach w prozie Brunona Schulza
}

\begin{abstract}
Naróg Aleksandra, Ekstaza i "nicość egzystencji”. O obrazach cielesności i jej barwach w prozie Brunona Schulza [Ecstasy and the "Emptiness of Existence". On the Images of Corporality and its Colours in the Prose of Bruno Schulz]. „Przestrzenie Teorii” 33. Poznań 2020, Adam Mickiewicz University Press, pp. 191-207. ISSN 1644-6763. DOI 10.14746/pt.2020.33.9.

The aim of the following study is to investigate two creations of Jacob's corporality evoking disgust in the short stories A Visitation, Birds and The Night of the Great Season from The Cinnamon Shops. My main field of interest is the connections between colours and form which surround Jacob's body and evoke disgust. The context for the following study was the theoretical concepts of Mary Douglas, Julia Kristeva, Agata Bielik-Robson and Michał Paweł Markowski.
\end{abstract}

KEYWORDS: Bruno Schulz, The Cinnamon Shops, corporality, colour, disgust, affect

Już wówczas miasto nasze popadało coraz bardziej w chroniczną szarość zmierzchu, porastało na krawędziach liszajem cienia, puszystą pleśnią i mchem koloru żelaza. Ledwo rozpowity z brunatnych dymów i mgieł poranka - przechylał się dzień od razu w niskie bursztynowe popołudnie, stawał się przez chwilę przezroczysty i złoty jak ciemne piwo, ażeby potem zejść pod wielokrotnie rozczłonkowane, fantastyczne sklepienie kolorowych i rozległych nocy ${ }^{1}$.

Nieprzypadkowo barwą otwierająca i zamykająca Nawiedzenie - drugie z kolei opowiadanie Sklepów cynamonowych - jest „chroniczna szarość”. Przymiotnik „chroniczny” nasuwa konotację z doświadczeniem przewlekłej choroby, konotuje „wynaturzenie” materii i niszczacy ją upływ czasu. Kolor żelaza przechodzi płynnie w nacechowany żywym fermentem brąz oraz piękna, choć niepokojąca, widziana jak gdyby w goraczce feerię barw zmierzchu. Schulzowską narrację rozpoczynają związane z brudem i chorobą metafory „liszaja cienia” i „puszystej pleśni” - kończy je natomiast obraz „kupki kurzu”. Co istotne, szarość stanowi w palecie barw element pośredni między czernia a biela - w podobny sposób metaforyka związana z odpadkami kontrastuje z semantyczną niejednoznacznością rzeczownika „nawiedzenie”. Może się on kojarzyć zarówno z chrześcijańską topika zwiastowania, jak i nasuwać

${ }^{1}$ B. Schulz, Nawiedzenie, [w:] tegoż, Opowiadania. Wybór esejów i listów, red J. Jarzębski, Kraków-Wrocław 1998, s. 13. Wszystkie dalsze cytaty pochodzące z tego wydania oznaczam symbolem „N", wraz z podaniem numeru strony w nawiasie. 
odniesienia związane ze spirytyzmem. Opis miasteczka konstruowany jest na zasadzie topiki labiryntu: „ciagłych omyłek” towarzyszących zachwianiu pojęcia czasowości - wielodniowego, onirycznego błądzenia przez bohaterów po korytarzach ciemnego domu. Schulzowskie barwy zarówno fascynuja niczym szkiełka w kalejdoskopie, jak i budzą awersję, depresję i niepokój.

W Nawiedzeniu po raz kolejny pojawia się postać Adeli: „[...] która nie nadzorowana przez nikogo, spędzała dnie przed lustrami na rozwlekłej toalecie, zostawiając wszędzie ślady w postaci wyczesanych włosów, grzebieni, porzuconych pantofelków i gorsetów" ( $N$ 13). Materialne ślady obecności kobiety - włosy i porozrzucane części garderoby - stają się dla narratora opowiadania milczącymi „świadkami” jej egzystencji. Równocześnie, przedmioty te znajdują się na granicy fascynacji i wstrętu. Włosy stanowią, obok paznokci i wydzielin fizjologicznych, jeden z krańcowych elementów ciała w ujęciu Mary Douglas. Jak zauważa badaczka: „[...] wszelkie obrzeża są groźne. Ich przesuwanie w tę i ową stronę zmienia kształt fundamentalnego doświadczenia. Każda struktura pojęciowa jest wrażliwa w obszarach końcowych"2. Postać służącej zyskuje przez to siłę mogącą zarazem konstruować świat przedstawiony, jak i poddawać go dekonstrukcji. Niższe piętra domu w opowiadaniu Schulza zajmowane są natomiast przez śpiących subiektów. Opis podnoszenia się młodych mężczyzn z łóżek również oparty jest na podkreśleniu budzącej wstręt brzydoty ich ciał:

W świetle pozostawionej przezeń świecy wywijali się leniwie z brudnej pościeli, wystawiali, siadając na łóżkach, bose i brzydkie nogi i z skarpetką w ręce oddawali się jeszcze przez chwilę rozkoszy ziewania - ziewania przeciagniętego aż do lubieżności, do bolesnego skurczu podniebienia, jak przy tęgich wymiotach ( $N$ 14).

Ziewanie, przypominające czynność zwracania pokarmu, przynosi uczucie pełnej rozkoszy - równocześnie jednak powoduje doznanie obrzydzenia. W eseju Potęga obrzydzenia Julia Kristeva interpretuje wy-miot (abiekt, to, co poza pod-miotem) jako element w najsilniejszy sposób kwestionujący ontologiczny status egzystencji. Łamie ono również ustanowione przez tradycyjną myśl filozoficzną reguły „silnej podmiotowości”. Jak pisze badaczka:

Wy-miot jest na zewnątrz, z dala od całości, której reguł gry, jak się wydaje, nie rozpoznaje. A jednak będąc na wygnaniu to, co wstrętne, nieprzerwanie rzuca wyzwanie swemu panu. Nie dając (mu) znaku, wywołuje wyładowanie, wstrząs, krzyk ${ }^{3}$.

Obrzydzenie staje się doświadczeniem związanym ze świadomością płynności granic świata - oraz paradoksalną afirmacja „braku” konsty-

${ }^{2}$ M. Douglas, Czystość i zmaza, przeł. M. Bucholc, Warszawa 2010, s. 155.

${ }^{3}$ J. Kristeva, Potega obrzydzenia. Esej o wstręcie, przeł. M. Falski, Kraków 2007, s. 8. 
tuującego podmiotowość: „[...] Wyobrażona dziwność i realne zagrożenie; wzywa nas, a w końcu pochłania”4. Jak pisze Kristeva, wymiot, „kieruje ,ja” ku „nie-ja”, wybija z ustalonego porządku świata i sytuuje podmiot na jego granicach $^{5}$. W Nawiedzeniu doświadczenia obrzydzenia łączą się z pierwotną cielesnością. Opis mężczyzn opiera się na zapisie doznawania wstrętu - „skurcz podniebienia”, związany równocześnie z bólem i lubieżnościa, łaczy w sobie obie te cechy. Nuda nieustannie związana jest tu z melancholia, a jedyną możliwą obroną materii - i bohaterów opowiadań - przed doświadczeniem „nicości egzystencji” staje się chwilowa, chorobliwa ekstaza. Jest to równocześnie jedno z podstawowych doświadczeń opisywanych przez literaturę i filozofię modernizmu. Analizując źródła związków nudy, ekstazy i melancholii, Michał Paweł Markowski przywołuje kontekst filozofii Martina Heideggera i Emila Ciorana ${ }^{6}$. Dla obu filozofów nuda stanowi punkt wyjścia samego procesu egzystencji, dzięki któremu może ona ulegać nieustannym przeobrażeniom. Agata Bielik-Robson, opisując nowoczesne i ponowoczesne konteksty tej kategorii, posługuje się Kunderowską metaforą „lekkości” i „ciężaru”. Jak pisze badaczka: „,...] to dylemat wyboru między inicjacją w kulturę, która opiera się na "melancholijnej i nużącej» obsesji pamiętania, a życiem, które nie chce i nie może żyć w dusznej atmosferze "melancholii i znużenia»" Prozę Schulza charakteryzowałoby w tym ujęciu ciagłe napięcie między sfera „nagiego życia”, a próbująca je zdominować przestrzenią pamięci materii.

Odczuwanie wstrętu charakteryzuje opis wielu zaułków domu w $\mathrm{Na}$ wiedzeniu; stanowi rodzaj zapowiedzi wątków obecnych w późniejszych opowiadaniach: ,[...] w kątach siedziały nieruchomo wielkie karakony, wyogromnione własnym cieniem" (N 14). Narrator określa czarne owady mianem „płaskich, bezgłowych kadłubów”. Opis postaci ojca łączy się z choroba, na która zapada Jakub - w pokoju ojca znajdują się rozmaite leki, a choroba niesie ze sobą szczególne doświadczenie sensoryczne, związane ze zjawiskiem synestezji: ,gorzkiego zapachu choroby osiadając[ego] na dnie pokoju" ( $N$ 14). Jakub jest postacią równocześnie wyłamującą się z porządku nudy, jak i nieustannie w nią popadająca. Nawiązując relacje z tym, co zwierzęce, podlega serii fantastycznych, groteskowych przemian: w jednej z nich naśladuje wiszącego na ścianie wypchanego „sępa lub koguta”, który: „,...] z wzrokiem zamglonym i z miną chytrze uśmiechnięta

${ }^{4}$ Tamże, s. 10.

${ }^{5}$ Tamże, s. 20.

${ }^{6}$ M.P. Markowski, Powszechna rozwiazłość. Schulz, egzystencja, literatura, Kraków 2012 , s. 74 .

${ }^{7}$ A. Bielik-Robson, Melancholia i ekstaza, [w:] Nuda w kulturze, red. P. Czapliński, P. Śliwiński, Poznań 1999, s. 29. 
trwał godzinami, ażeby z nagła przy czyimś wejściu zatrzepotać rękoma jak skrzydłami” (N 20).

Józef zauważa, że postać ojca: „pogrąża się z dniem każdym głębiej w zawiłe i dziwaczne afery [...]. Wiecznie zaaferowany, chorobliwie ożywiony, z wypiekami na suchych policzkach nie zauważał nas i przeoczał" ( $N 15)$. Choroba łączy się z fizjologicznie zauważalnym szaleństwem, w które zaczyna popadać Jakub. Przemiany ojca budzą w narratorze i pozostałych bohaterach opowiadania równoczesną fascynację i lęk. To właśnie ten paradoks będzie kształtował substancję jego osobowości. Bohater pochłonięty jest przez pracę i prowadzenie ksiag rachunkowych w sklepie; pragnie jednak uwolnić się od tego zajęcia - poszukuje „,czegoś więcej” - tego, co sytuuje się nie w sferze ducha, a w przestrzeni cielesności:

Chwilami wynurzał głowę z tych rachunków, jakby dla zaczerpnięcia tchu, otwierał usta, mlaskał z niesmakiem językiem, który był suchy i gorzki, i rozglądał się bezradnie, jakby czegoś szukając ( $N 15)$.

Równocześnie, uwagę Józefa przykuwa opis załatwiania przez Jakuba w osobliwy sposób swoich potrzeb fizjologicznych:

Wówczas bywało, że zbiegał po cichu z łóżka w kąt pokoju, pod ścianę, na której wisiał zaufany instrument. Był to rodzaj klepsydry wodnej albo wielkiej fioli szklanej, podzielonej na uncje i napełnionej ciemnym fluidem. Mój ojciec łączył się z tym instrumentem długą kiszką gumowa, jakby kręta, bolesną pępowiną, i tak połączony z żałosnym przyrządem - nieruchomiał w skupieniu, a oczy jego ciemniały, zaś na twarz przybladłą występował wyraz cierpienia czy jakiejś występnej rozkoszy (N 15).

Wstręt łączy się tu z silną fascynacją; cierpienie jest być nieodróżnialne od „występnej rozkoszy” - przyjemności. Ojciec w groteskowy sposób zespaja się z nocnikiem poprzez długa gumową kiszkę - przypomina ona pępowinę, wskazującą na kojarzacą się z porodem pierwotność. Żółć uryny przypomina pojawiającą się wcześniej bursztynową barwę zachodzącego słońca.

Nie widziałem nigdy proroków Starego Testamentu, ale na widok tego męża, którego gniew boży obalił, rozkraczonego szeroko na ogromnym porcelanowym urynale, zakrytego wichrem ramion, chmurą rozpaczliwych łamańców, nad którymi wyżej jeszcze unosił się głos jego, obcy i twardy - zrozumiałem gniew boży świętych mężów ( $N 17)$.

Kontakt ojca z boskością naznaczony jest spotkaniem ze sfera odpychającej fizyczności twarzy wyimaginowanego Demiurga: „,...] przykładał ogromną twarz do górnych szyb okna, na których płaszczył się potwornie mięsisty nos jego" ( $N$ 17). Jakub zmaga się z doświadczeniem obrzydzenia musi dać mu świadectwo „usty i wnętrznościami”, w sferę logosu włączyć to, co cielesne. Głosy obojga „herezjarchów” określane są jako „[...] wielki 
zgiełkliwy hałas, burz zmieszanych szlochów i przekleństw" ( $N$ 17). Ten rodzaj mowy wiąże się porzuceniem tradycyjnego Logosu i równoczesną „groteskową boskością" ojca:

W świetle błyskawicy ujrzałem ojca mego w rozwianej bieliźnie, jak ze straszliwym przekleństwem wylewał potężnym chlustem w okno zawartość nocnika w noc szumiąca jak muszla ( $N 18)$.

Zachowanie postaci zostaje skontrastowane z jej niepełnym ubiorem oraz opisem zawartości nocnika; powodującym pojawienie się obrzydzenia, od którego ojciec nie może się uwolnić. Podobnie, jak w opowiadaniu Pan, nieczystości stają się tu zarówno materialną sferą wstrętu, jak i elementem powiązanym z demiurgiczną boskością. Kolejna część Nawiedzenia stanowi opis nietypowej „przemiany” Jakuba - jego stopniowego zaniku, przechodzenia w martwiejący brąz:

Zauważyliśmy wówczas wszyscy, że ojciec zaczął z dnia na dzień maleć jak orzech, który zsycha się wewnątrz łupiny ( $N 19)$.

Ojciec w powolny sposób kurczy się - naturalny proces starzenia opisywany jest jako stopniowe, przeczące prawom fizyki „zmniejszanie powierzchni” ciała. Zanik ten nie jest jednak kojarzony z całkowitym pozbawieniem sił witalnych - jak określa to Józef: „,...] stan jego zdrowia, humor, ruchliwość zdawały się poprawiać [...] (N 19)". W paradoksalny sposób zniknięciu energii towarzyszy tu jej przyrost. Równocześnie, Jakub coraz bardziej oddala się poprzez swoje przemiany od reszty bohaterów opowiadania: „Węzeł po węźle odluźniał się od nas, punkt po punkcie gubił związki łączące go ze wspólnotą ludzką" ( $N$ 20). Jakub wydaje się być postacią pochodząca z „innego rejestru”, w luźny sposób związaną z codziennością - właściwą mu sfera staje się to, co wybijające z określonego porządku świata, nierzeczywiste. Jak pisze Żaneta Nalewajk w prozie Schulza doznania emocjonalne bardzo często znajdują swój wyraz w motywie transformującej się cielesności ${ }^{8}$. Badaczka określa emocje jako rodzaj „mimiki wobec świata”, w przyjmowaniu której kluczowe okazuje się doświadczenie rozpadu cia$\nmid a^{9}$. Postacie cechuje „obecność ulegająca pokawałkowaniu”, przechodząca ciagłe metamorfozy:

To, co jeszcze z niego pozostało, to trochę cielesnej powłoki i ta garść bezsensownych dziwactw - mogły zniknąć pewnego dnia, tak samo nie zauważone jak szara kupka śmieci, gromadząca się w kącie, którą Adela co dzień wynosiła na śmietnik (N 20).

${ }^{8} \dot{Z}$. Nalewajk, W stronę perspektywizmu. Problematyka cielesności w prozie Witolda Gombrowicza i Brunona Schulza. Prolegomena, Gdańsk 2010, s. 116.

${ }^{9}$ F. Chirpaz, Ciało, przeł. J. Migasiński, Warszawa 1998, s. 41, cyt. za: Ż. Nalewajk, dz. cyt., s. 319 . 
Finał opowiadania odzwierciedla całą niezwykłość dynamiki przemiany Jakuba: z demiurga staje się on „szarą kupki śmieci”. Równocześnie, porównanie bohatera do odpadków zamiatanych przez Adelę, rysuje silną dychotomię uwidaczniająca się w relacji między obydwoma postaciami, w której - w dużym uproszczeniu - ojciec sytuował się będzie po stronie tego, co rozumowe, służąca - tego, co cielesne. Ta zmienność stanowi równocześnie wyraz strategii „pulsującego” obrazowania świata w Sklepach cynamonowych - jak pisze Jerzy Jarzębski:

[...] obrazy Schulza dają się [...] zobaczyć, tylko że nie jako wyraźna w formie scena, ale jako drgająca, pulsująca światłem, barwami, zmiennym kształtem magma, utrzymująca jednak na dłużej pewien wspólny kształt ${ }^{10}$.

$$
* * *
$$

Kolor żółty - tło narracji Sierpnia i Nawiedzenia - jest również barwą otwierająca Ptaki. Narrator kojarzy żółć z doświadczeniem nudy oraz zapadaniem zimy - pora ta staje się czasem uśpienia siły życia („Nadeszły żółte, pełne nudy dni zimowe”11). Kolor świtu jest natomiast „mętnożółty”; towarzyszy mu czerń, stanowiąca element opisu obrazu „gontowych strzech”, w które dma „ciemne płuca wichrów”; „czarne piszczałki organów diabelskich” (P21). Czerń to zarazem barwa krążących po niebie ptaków - wron, porównanych do „żywych liści”. Materię konstruującą świat cechuje wybrakowanie i zniszczenie: „Zrudziała ziemię pokrywał dziurawy, przetarty, za krótki obrus śniegu" ( $P$ 21). Krzysztof Stala zauważa, że pierwsze zdania Ptaków w najpełniejszy sposób przedstawiają literacką strategię opisywania czasu w prozie Schulza. Cechuje ją: „[...] oddzielenie, odklejenie czasu od świata - ucieka on w figury, w obrazy, poza rzeczywistość, zostawiając tę ostatnią na pastwę «czystego trwania» - bezruchu, zastygnięcia w hieratyczności monumentu” ${ }^{2}$. Wspomniane „przejście poza rzeczywistość” staje się jedną z głównych cech narracji opisującej metamorfozy zachodzące między ludźmi, zwierzętami i przedmiotami.

Postacia, wokół której ponownie koncentruje się akcja całego opowiadania, jest Jakub. Upodabnia się on do groteskowego, stopniowo „degradujacego" swoją pozycję demiurga, którego rolę przyjmował już w Nawiedzeniu. Ojciec „nie wychodzi z domu”, a jego głównym zajęciem stają się studia nad

${ }^{10}$ J. Jarzębski, Prowincja centrum. Przypisy do Schulza, Kraków 2005, s. 49.

${ }^{11}$ B. Schulz, Ptaki, [w:] tegoż, Opowiadania. Wybór esejów i listów..., s. 21. Dalsze cytaty pochodzace z opowiadania oznaczać będę symbolem „P”, wraz z podaniem numeru strony w nawiasie.

${ }^{12}$ K. Stala, Na marginesach rzeczywistości: o paradoksach przedstawiania w twórczości Brunona Schulza, Warszawa 1995, s. 115. 
„nigdy nie zgłębioną istotą ognia”. Jego eksperymenty maja - zaznaczający się już na początku opowiadania - wymiar sensualny, opierający się na przeciwstawnych doznaniach zmysłowych o „chłodnej”, niemal egzotycznej kolorystyce: ,„[...] wyczuwał słony, metaliczny posmak i wędzony zapach zimowych płomieni, chłodną pieszczotę salamander" (P 21). Studia nad żywiołami prowadzone przez Jakuba stopniowo przekształcają się w obserwacje dotyczące świata zwierząt - oraz domową hodowlę ptaków:

Z wielkim nakładem trudu i pieniędzy sprowadzał ojciec z Hamburga, z Holandii, z afrykańskich stacyj zoologicznych zapłodnione jaja ptasie, które dawał do wylęgania ogromnym kurom belgijskim ( $P 23)$.

Jakub staje się nie tylko znaną z większości opowiadań autora Sklepów cynamonowych figura demiurga, ale także modernistycznym kolekcjonerem przedmiotów i zwierząt w rozumieniu Waltera Benjamina. Przypomina bowiem „[...] zbieracza, który w marzeniach nie tylko przenosi się w jakiś daleki lub miniony świat, lecz widzi się także w lepszym świecie, w którym wprawdzie ludzie nadal nie mają tego, czego trzeba, rzeczy jednak wolne są od przymusu użyteczności”"13. Szczególna pasja Jakuba przybiera jednak znacznie głębszy wymiar - towarzyszy jej stopniowa, groteskowa przemiana ciała, rozpoczynająca się w surrealistyczny sposób poprzez zmianę dotychczasowej perspektywy jego położenia. Narrator pisze o częstym ustawianiu się ojca „w ptasiej perspektywie”; równocześnie, wycofując się z reguł codziennej komunikacji, Jakub przestaje porozumiewać się z matka. Porzuca mowę na rzecz „przysłuchiwania się” odgłosom płynącym ze szpar podłogi, natężenia uwagi nad prowadzonymi przez siebie "studiami”. Jego twarz opisywana jest poprzez wrażenie „nieobecności” i „targania drgawkami”, stanowiące zapowiedź przyszłej przemiany:

O każdej porze dnia można go było widzieć, jak - przykucnięty na szczycie drabiny majstrował coś przy suficie, przy karniszach wysokich okien, przy kulach i łańcuchach lamp wiszących. Zwyczajem malarzy posługiwał się drabina jak ogromnymi szczudłami i czuł się dobrze w tej ptasiej perspektywie, w pobliżu malowanego nieba, arabesek i ptaków sufitu (P 21-22).

Działania ojca w dalszym rozwoju fabuły cechuje coraz większe zainteresowanie tym, co zwierzęce. Elementem łączaccym człowieka i zwierzę staje się afektywna ekspresja: narrator dwukrotnie wspomina o żywionej przez ojca namiętności, posiadającej dwojaki wymiar: „myśliwski” i „artystyczny”. Kolekcjonowanie ptaków łączy w sobie wymiar materialny z wymiarem symbolicznym, duchowym; nietzscheański żywioł apolliński z żywiołem

${ }^{13}$ W. Benjamin, Paryż - stolica XIX wieku. Exposé, [w:] tegoż, Pasaże, przeł. I. Kania, Kraków 2010, s. 56. 
dionizyjskim. Jego działanie jest zarazem rodzajem międzygatunkowej transgresji: określone zostaje przez narratora jako „[...] głębsza zoologiczna sympatia kreatury dla pokrewnych, a tak odmiennych form życia, eksperymentowanie w nie wypróbowanych rejestrach bytu" ( $P$ 23). Fascynacja ta szybko ulega jednak obróceniu w „grzeszny i przeciwny naturze obrót”. Ojciec, przez swoje upodobania do eksperymentów, wyłącza się z rzeczywistości: „nie może wróść sobą w żadna realność” ( $P$ 22). Skutkiem jego działań staje się w finale Ptaków groteskowe upodobnienie do stworzeń, wśród których nieustannie przebywa:

Niekiedy przez zapomnienie zrywał się z krzesła przy stole i trzepiąc rękoma jak skrzydłami, wydawał pianie przeciąłe, a oczy zachodziły mu mgłą bielm ( $P 25)$.

Znaczenie symboliki ptaków może być powiązane z dialektyką świętości i profanacji, nieczystości i porządku. Ptaki stanowią tradycyjną emanację wzniosłości; ich pozytywne znaczenie symboliczne często ulega tu jednak degradacji - kieruja one Jakuba w sferę szaleństwa ${ }^{14}$. Tomasz Olchanowski zwraca uwagę na odwrócenie znaczenia mitologicznego w obecnych u autora Sklepów cynamonowych przedstawieniach ptaków. W ujęciu Mircei Eliadego są one „przewodnikami dusz”; symbolem „ekstatycznej podróży do nieba i w zaświaty" ${ }^{15}$. Kieruja one jednak w paradoksalny sposób Jakuba w stronę tego, co „ziemskie”, związane z „czarnym nurtem” oraz przestrzenią międzygatunkowej hybrydyczności. Próbę interpretacji związków ptaków z doświadczeniem wstrętu może przynieść analiza ich znaczenia religijnego w kulturze żydowskiej. Mary Douglas, przywołując fragment Księgi Kapłańskiej, wymienia kilkanaście gatunków zaliczanych do „nieczystych” i łamiących tabu pokarmowe - należą do nich między innymi pojawiające się na początku opowiadania czarne kruki ${ }^{16}$. Analizując sposób konstruowania tabu związanego ze zwierzętami (przenoszące się także na reguły dotyczące spożywania pokarmów) w judaizmie, badaczka zwraca uwagę na związki procesu doświadczania wstrętu z dawnymi zasadami religijnymi. Jak zauważał rozwijający Freudowską teorię obrzydzenia Julian Hirsch:

${ }^{14}$ Por. P. Millati, Ptaki, [w:] Stownik schulzowski, red. J. Jarzębski, W. Bolecki, S. Rosiek, Gdańsk 2006, s. 298.

${ }^{15}$ M. Eliade, Szamanizm i archaiczne techniki ekstazy, przeł. K. Kocjan, Warszawa 1994, s. 108, cyt. za: T. Olchanowski, Jungowska interpretacja mitu ojca w prozie Brunona Schulza, Białystok 2001, s. 38.

${ }^{16}$ Przywoływany przez Mary Douglas fragment Księgi Kapłańskiej: „Spośród ptaków będziecie mieli w obrzydzeniu, i nie będziecie ich jedli, bo są obrzydliwościa, następujące: orzeł, sęp czarny, orzeł morski, (14) wszelkie gatunki kani i sokołów, (15) wszelkie gatunki kruków, (16) struś, sowa, mewa, wszelkie gatunki jastrzębi, (17) puszczyk, kormoran, ibis, (18) łabędź, pelikan, ścierwik, (19) bocian, wszelkie gatunki czapli, dudek i nietoperz". M. Douglas, dz. cyt., s. 83. 
Wstręt do woni rozkładu, do robactwa czy ekskrementów nie byłby zatem prymarnie zmysłowo - bezpośrednim wstrętem, lecz przeżytkiem tabu opartych na magiczno-religijnych fundamentach, których wartość afektywna przeżyła ich dawno zapomniane znaczenie, po czym została zracjonalizowana na pozór przekonywającymi argumentami ${ }^{17}$.

Pokój Jakuba opisywany jest poprzez metaforykę związaną z czernia, co pozwala odczytać opis spotkania z innym gatunkiem w kontekście Freudowskiego „niesamowitego”: „zakazanego nurtu”, któremu poddaje się ojciec. Widoczny jest on również w samym opisie wykluwajacych się z jaj ptaków - są one potworne, budzące lęk, a zarazem groteskowe - określane jako „[...] prawdziwe dziwotwory w kształcie i ubarwieniu” (P 23). Cechuje je „pulsowanie życia”; równocześnie przypominają one narośle, kojarzone sa z elementem chorobliwym, wymagającym „odcięcia” od reszty zdrowego ciała. Zostają porównane przez narratora do pnących się pąków kwiatów, Jakub jest natomiast „ogrodnikiem chodzącym wzdłuż inspektów z kaktusami”, zarówno sprawującym władzę nad okazami, jak i poddającym się ich działaniu, by następnie upodobnić się do ptaków w wyglądzie i zachowaniu. Ojciec:

[...] wywabiał z nicości te pęcherze ślepe, pulsujace życiem, te niedołężne brzuchy, przyjmujące świat zewnętrzny tylko w formie jedzenia, te narośle życia, pnące się omackiem ku światłu (P 23).

W dalszej części opowiadania uwagę Józefa zwraca stojący w pokoju ogromny kondor, porównany do „chudego ascety” i „buddyjskiego lamy”. Między Jakubem a ptakiem zawiązuje się niewysłowione porozumienie, obecne w wyraźny sposób nie tylko w fizjonomii, ale również w zachowaniu. Tym, co łączy Jakuba ze sferą zwierzęcego, staje się cielesność; zwłaszcza skóra i oczy, upodobniające go do ptaka, z którym zaczyna żyć w nietypowej symbiozie. Ptak przypomina starszego brata ojca, a poszczególne części ich ciał odpowiadają sobie na zasadzie analogii:

Ta sama materia ciała, ścięgien i pomarszczonej twardej skóry, ta sama twarz wyschła i koścista, te same zrogowaciałe, głębokie oczodoły. Nawet ręce, silne w węzłach, długie, chude dłonie ojca, z wypukłymi paznokciami, miały swój analogon w szponach kondora (P 24).

Cechą łączącą Jakuba z ptakiem jest starość - kondor przypomina narratorowi „wyschłą mumię”. Jak zauważa Jerzy Jarzębski jest to częsta strategia przedstawiania schyłku życia w opowiadaniach Schulza, opierająca się na rodzaju „rozprzężenia kształtu”, polegającego na stopniowym upodabnianiu się rysów twarzy człowieka do fizjonomii zwierzęcia. Forma egzystencji ojca określana zostaje mianem „regresji”, opierającej się na ro-

${ }^{17}$ W. Menninghaus, Wstręt: teoria i historia, przeł. G. Sowiński, Kraków 2008, s. 248. 
dzaju „pół-życia” przemieniającego się w zwierzę człowieka ${ }^{18}$. Przemiana ta naznaczona jest również wstrętem - oprócz fizycznego podobieństwa, ojca łączy z ptakiem prozaiczny proces defekacji: ,[...] kondor używał z moim ojcem wspólnego naczynia nocnego" ( $P$ 24). Metamorfoza ta sytuuje się na pograniczu komizmu i powagi: Jakub próbuje „obrócić swoje położenie w żart” poprzez śmiech. Powyższy fragment Tomasz Bocheński interpretuje jako jeden z najwyraźniejszych przejawów Schulzowskiego czarnego humoru, w którym splatają się ze soba: „,...] subtelność i zmysłowa dosadność, łudzenie powierzchownymi asocjacjami i splatanie wielu warstw znaczeń" ${ }^{\prime \prime}$. Zmysłowa fascynacja łączy się z równoczesnym komizmem i przerażeniem w ujęciu Kristevej to właśnie śmiech stanowi jedną z form obrony przed doświadczeniem wstrętu - staje się sposobem jego sublimacji i wyparcia ${ }^{20}$ :

Niekiedy, przez zapomnienie zrywał się z krzesła przy stole i trzepiąc rękoma jak skrzydłami, wydawał pianie przeciagłe, a oczy zachodziły mu mgła bielma. Potem, zawstydzony, śmiał się razem z nami i starał się ten incydent obrócić w żart (P 25).

Ciała ptaków są niepełne i kalekie, podlegają różnorodnym deformacjom. Narrator nazywa je: „monstrami syczącymi żarłocznie czeluściami gardła”; „jaszczurami o wątłym, nagim ciele garbusów” (P 23). Ptaki określane są również mianem „dziwotworów” i „smoczego pomiotu”. Ich cielesność oparta jest na nieustannym „pulsowaniu” siły życia, łamiącego ustaloną relację między wnętrzem a zewnętrzem: „Umieszczony w koszykach, w wacie, smoczy ten pomiot podnosił na cienkich szyjach ślepe, bielmem zarosłe głowy, kwacząc bezgłośnie z niemych gardzieli” ( $P$ 23). Znajdują się w sferze potencjalności; oczekują na swój naturalny rozwój. W dalszej części opowiadania opisywany on jest jako pełna barw i dźwięków metamorfoza:

W parę tygodni później, gdy te ślepe pączki życia pękły do światła, napełniły się pokoje kolorowym pogwarem, migotliwym świergotem swych nowych mieszkańców. Obsiadały one karnisze firanek, gzymsy szaf, gnieździły się w gęstwinie cynowych gałęzi i arabesek wieloramiennych lamp wiszących ( $P$ 23).

Wielobarwne postaci zwierząt odzwierciedlają tkwiącą w Jakubie siłę wybrakowanego życia: mającego potężną moc, ale zarazem naznaczonego zniekształceniem i choroba. Autor Sklepów cynamonowych posługuje się w opisach ptaków strategia reifikacji, porównując je do obecnych w domu przedmiotów - „żywego dywanu”, „barwnej, falującej grządki” przekształcającej się w „ruchome kwiaty”. Samo pojawienie się ptaków nasuwa również konotacje biblijne: pokój staje się „arką Noego”, na której ojciec urządza

\footnotetext{
${ }^{18}$ J. Jarzębski, Schulz, Wrocław 1999, s. 184-186.

${ }_{19}$ T. Bocheński, Czarny humor w twórczości Witkacego, Gombrowicza, Schulza. Lata trzydzieste, Kraków 2005, s. 161.

${ }^{20}$ J. Kristeva, dz. cyt., s. 155.
}

\begin{tabular}{l|l} 
Aleksandra Naróg & $\mathbf{2 0 0}$ \\
&
\end{tabular}


„ptasie wesela”. Świat opowiadania cechuje doświadczenie hiperbolizacji i cyklicznej powtarzalności, w której to, co ludzkie, zostaje zrównane z tym, co zwierzęce:

Nawet długo po zlikwidowaniu ptasiego gospodarstwa utrzymywała się w świecie ptasim ta tradycja naszego domu, i w okresie wiosennych wędrówek spadały nieraz na dach nasz całe chmary żurawi, pelikanów, pawi i wszelkiego ptactwa ( $P$ 25).

Fantastyczny deszcz ptaków nie jest, paradoksalnie, utożsamiany z biblijną klęska - przekształca się w symbol dobrobytu i urodzaju. „Nadmiar” materii powodowany przez pojawienie się ptaków jest jednak w dalszym ciagu akcji opowiadania powodem chaotycznego rozprzężenia jej sił oraz stopniowej przemiany postaci ojca. Hodowane przez niego ptaki zaczynaja wydawać różnorodne dźwięki: „szum, trzepot, pianie, tokowanie i gulgot”. Odgłosy te dalekie są od śpiewu, budzą niepokój i wrażenie pulsowania materii. Towarzyszy temu, podobnie jak w Nawiedzeniu, stopniowe zanikanie:

Tak straciliśmy ojca z widoku na przeciag kilku tygodni. Rzadko tylko schodził do mieszkania i wtedy mogliśmy zauważyć, że zmniejszył się jakoby, schudł i skurczył (P 25).

Dominacja materii związanej ze zwierzęcością powoduje stopniowe osłabienie ciała Jakuba, zawiązującego afektywną wspólnotę z hodowanymi przez siebie ptakami. Adam Lipszyc zauważa, że w Sklepach cynamonowych ptaki przynależą do świata „zdegradowanej materii” - tandety, obdarzonej „papierowa natura” i zarazem do świata stanowiącego obraz poetyckiej „dekompozycji prawa” narzucanego przez reguły realizmu ${ }^{21}$. Obraz ptaków może mieć w tym miejscu znaczenie szersze od poetyckiej metafory. Stefan Chwin, analizując opowiadanie Schulza, wiąże opisy „grzesznych manipulacji” Jakuba z niewątpliwie zaznaczającymi się na początku XX wieku wpływami Darwinowskiego ewolucjonizmu ${ }^{22}$. Jak przypomina badacz, autor Komety był świadkiem pojawienia się możliwości hodowania zwierząt transgenicznych oraz rozwoju inżynierii medycznej, umożliwiającej eksperymenty $\mathrm{z}$ tradycyjna formą ludzkiego ciała. Zwrócenie uwagi na ten kontekst pozwala na próbę lektury opowiadania w kontekście opisu międzygatunkowej deformacji, tworzącej z ptaków (oraz ludzi) istoty hybrydyczne. Ciało staje się w ujęciu ówczesnego świata nauki „plastyczną cząstką nieskończonego strumienia życia", literatura natomiast stanowi próbę odpowiedzi na podejmowane przez niego postulaty. Co więcej, jak podkreśla Sara Ahmed,

${ }^{21}$ A. Lipszyc, Schulz na szaro, Schulz przed prawem, [w:] Schulz. Przewodnik „Krytyki Politycznej”, Warszawa 2012, s. 53.

${ }^{22}$ S. Chwin, „Grzeszne manipulacje”. Historia sztuki a historia medycyny, [w:] Czytanie Schulza. Materiaty międzynarodowej sesji naukowej Bruno Schulz-w stulecie urodzin $i$ w pięćdziesięciolecie śmierci, red. J. Jarzębski, Kraków 1994, s. 279. 
to właśnie Darwinowskie ujęcie doświadczenia wstrętu jako „złego smaku” stoi u źródeł nowoczesnego pojmowania tej kategorii ${ }^{23}$.

Obrazy pojawiajace się w Nawiedzeniu i Ptakach znajdują swój finał w Nocy wielkiego sezonu. Opowiadanie otwiera - ponownie kojarzący się z doświadczeniem wynaturzonego nadmiaru - opis „trzynastego”, dodatkowego miesiąca. Stanowi on zarazem rodzaj zminiaturyzowanej wykładni Schulzowskiej filozofii czasu; kosmogonii, w której znakiem szczególnym zarówno czasu, jak i materii staje się rodzaj niepokojącego „naddatku”, „rozplenienia”, „rozgałęzienia”, kwestionującego pewny status ontologiczny rzeczywistości. Cechują je zdziwaczenie i wyrodność - fizyczna, wstrętna deformacja:

Każdy wie, że w szeregu zwykłych, normalnych lat rodzi niekiedy zdziwaczały czas ze swego łona lata inne, lata osobliwe, lata wyrodne, którym, jak szósty, mały palec u ręki, wyrasta kędyśs trzynasty, fałszywy miesiąc ${ }^{24}$.

Nieustannie powraca opis zatrzymania w rozwoju: trzynasty miesiąc określany jest jako kalekie „dziecko późno spłodzone”, „garbusek”, „w połowie uwiędła odrośl" (NW 97). Równocześnie pojawia się tu metaforyka związana zarówno ze sferą pokarmu, jak i potwornością opisywanej materii: „Dni dziczki, dni-chwasty, jałowe i idiotyczne [...], dni kaczany, puste i niejadalne - dni białe, zdziwione i niepotrzebne”, przypominające „palce potworkowatej ręki, pączkujące i zwinięte w figę" (NW 97). Percepcja czasu związana jest z działaniem zmysłu wzroku oraz „wylewania się” i nadmiaru materii - białej kartki, po której „[...] oczy, naczytane do syta i pełne treści, broczyć mogą obrazami i gubić kolory (NW 98)". Charakterystyczna dla opowiadania staje się - oprócz bieli - pojawiająca się już w Ptakach żółć, kojarzona z kolorem księgi i kartkami „pustego kalendarza” przemijających dni. Czasowi temu przeciwstawiony jest tytułowy „wielki sezon”. Staje się on rodzajem barwnego „karnawału” - wydarzenia organizującego na krótki czas życie mieszkańców miasteczka:

Przychodziła pora Wielkiego Sezonu. Ożywiały się ulice. O szóstej godzinie po południu miasto zakwitało gorączka, domy dostawały wypieków, a ludzie wędrowali ożywieni jakimś wewnętrznym ogniem, naszminkowani i ubarwieni jaskrawo, z oczyma błyszczącymi jakąś odświętna, piękną i złą febrą (NW 101).

„Wielki sezon” wnosi zarazem do ustalonej kosmogonii rodzaj nowego, „naddanego porządku”, poddającego opisywany świat procesowi dezorga-

${ }^{23}$ S. Ahmed, Performatywność obrzydzenia, przeł. A. Barcz, „Teksty Drugie” 2014, 1, s. 169 .

${ }^{24}$ B. Schulz, Noc wielkiego sezonu, [w:] tegoż, Opowiadania. Wybór esejów i listów..., s. 97. Wszystkie dalsze cytaty pochodzące z tego wydania oznaczam symbolem „NW”, wraz $\mathrm{z}$ podaniem numeru strony w nawiasie. 
nizacji. W klasycznym ujęciu Bachtinowskim czas karnawału, oparty na żywiole parodii i profanacji, stanowi rozbicie ustalonego porządku społecznego ${ }^{25}$. Sam „wielki sezon” nie jest przez narratora określany w sposób jednoznacznie pozytywny. Tradycyjnie kojarzony z karnawałem żywioł śmiechu zostaje zastapiony przez doświadczenie choroby - towarzysząca mu „żółtą gorączkę”, febrę i wypieki na twarzy. Ludzie pojawiający się na ulicach porównani są do „płynącego rojowiska” oraz rozprzestrzeniającej się „wielkiej miazgi plotek”. Równocześnie, obraz tłumu podlega reifikacji, wpisujac się w uniwersalny rytm świata obumierajacej przyrody. Proces ten dotyczy również obserwujących rozgrywające się na ulicach wydarzenia mieszkańców miasta, przypominających: „[...] jesienne, suche makówki, sypiące makiem - głowy - grzechotki, głowy - kołatki" (NW 103). Pozornie drugoplanowe elementy opisu budzą w odbiorcy niepokój, konfrontując go z tym, co wstrętne. Rolę tę pełni między innymi obraz zabawy dzieci na ulicy miasta - dmuchanie przez nie kolorowych balonów przeradza się w rozrost „małych pęcherzyków” do rozmiaru „wielkich, gulgocących, rozpluskanych narośli", opisanych za pomoca neologizmów związanych z przejaskrawieniem cech zwierzęcych: „wyindyczenia” i „wykogucenia” Jakuba. Doświadczenie wstrętu ulega intensyfikacji w chwili zapadania zmierzchu:

I podczas gdy zabawy dzieci stawały się coraz bardziej hałaśliwe i splątane, wypieki miasta ciemniały i zakwitały purpura, nagle świat cały zaczynał więdnąć i czernieć, i szybko wydzielał się zeń majaczliwy zmierzch, którym zarażały się wszystkie rzeczy ( $N W 102)$.

Materia w opisie narratora jest tania i wybrakowana, określana mianem „wesołej tandety”. Towarzyszy jej podszycie „ciemnym zapachem grzybów” na zasadzie synestezji łączy ona w sobie dźwięki (,głuchy akompaniament najciemniejszych basów”) z tworzącymi rodzaj „malarskiej wizji” odcieniami brązu, określanymi mianem „kapitału jesieni”: „ochra, sangwina, rudością i sepią" (NW 101). Kluczowy dla całego opowiadania staje się opis ożywającej materii, wywołujaccej narastające obrzydzenie:

Zjadliwie i jadowicie szerzyła się ta zaraza zmierzchu wokoło, szła od rzeczy do rzeczy, a czego dotknęła, to wnet butwiało, czerniało, rozpadało się w próchno. Ludzie uciekali przed zmierzchem w cichym popłochu i naraz dosięgał ich ten trąd i wysypywał się ciemną wysypką na czole, i tracili twarze, które odpadały wielkimi, bezkształtnymi plamami, i szli dalej już bez rysów, bez oczu, tak że zmierzch roił się od tych larw porzuconych, sypiących się za ich ucieczką. Potem zaczynało wszystko zarastać czarna, próchniejącą kora, łuszczącą się wielkimi płatami, chorymi strupami ciemności (NW 102).

${ }^{25}$ Por. M. Bachtin, Problemy poetyki Dostojewskiego, przeł. N. Modzelewska, Warszawa 1970, s. 157. 
Zapadanie zmroku łączy się z coraz większym upodabnianiem się ludzi do owadów - „porzucanych larw”. Towarzyszy temu powodowany przez wszechogarniająca chorobę - „ciemną wysypkę trądu” - proces zanikania tożsamości postaci, widoczny poprzez „bezkształtność” rysów twarzy przechodniów oraz pozbawienie ich oczu. Zmierzch kojarzony jest ze wstrętem; ,jadem” i ,zarazą", staje się doświadczeniem wymykającym się racjonalizacji, poddającym świat przedstawiony natychmiastowej destrukcji. Obserwujący wydarzenia „wielkiego sezonu” Jakub chce utrzymać władzę nad siłą rozprzestrzeniającej się materii - jego ciało również podlega jednak chorobliwej deformacji:

Mój ojciec chodził zdenerwowany i kolorowy od wypieków, z błyszczącymi oczyma w jasno oświetlonym sklepie, i nasłuchiwał. [...] Jego ucho zdawało się w tej ciszy nocnej wydłużać i rozgałęziać poza okno: fantastyczny koralowiec, czerwony polip falujacy w mętach nocy [...]. Słyszał z rosnącym niepokojem daleki przypływ tłumów, które nadciagały (NW 103-104).

Ojciec, siedząc najczęściej w swoim pokoju - dawnym miejscu hodowli ptaków - pogrąża się w pracy: „,...] siedział jak w ptaszarni, na wysokim stołku, a gołębniki registratur szeleściły plikami papierów i wszystkie gniazda i dziuple pełne były świergotu cyfr" (NW 100). Równocześnie, na próżno szuka nieobecnych w sklepie subiektów, mających w symboliczny sposób bronić domu i sklepu przed naciagającymi tłumami. Symbolem erotycznej siły ponownie okazuje się tu Adela, wokół której zogniskowane jest erotyczne pragnienie groteskowo przerysowanych, brzydkich mężczyzn:

Tam stała zdyszana, błyszcząca i rozbawiona, trzepocaca z uśmiechem wielkimi rzęsami. Subiekci chichotali, przykucnięci pode drzwiami. Okno kuchni otwarte było na wielka, czarną noc, pełną rojeń i splątania ( $N W 105)$.

Obserwacja zachowania subiektów oraz zbliżanie się nadciagającego tłumu budzi gniew Jakuba, przybierającego cechy biblijnego proroka. Traci on panowanie nad rozprzestrzeniającą się w niekontrolowany sposób, „wymiotującą” materią: „Tak wylewały się zapasy szaf, wymiotowały gwałtownie, płynęły szerokimi rzekami. Wypływała barwna treść półek, rosła, mnożyła się i zalewała wszystkie lady i stoły" ( $N W 106)$. Ojciec zostaje skonfrontowany z przyjmującym cechy bałwochwalcze „beztroskim ludem Baala", a jego ciało poddane zostaje groteskowej deformacji:

Wyolbrzymiony gniewem, z głową spęczniałą w pięść purpurowa, wbiegł, jak walczacy prorok na szańce sukienne i ją przeciw nim szaleć. Wpierał się całym ciałem w potężne bale wełny [...]. Gdy ojciec mój, przerażony ohydą grzechu, wrastał gniewem swych gestów w grozę krajobrazu, w dole beztroski lud Baala oddawał się wyuzdanej wesołości. Jakaś parodystyczna pasja, jakaś zaraza śmiechu opanowała tę gawiedź. Jak można było żądać powagi od nich, od tego ludu kołatek i dziadków do orzechów! [...] (NW 105-106). 
Postacie uczestniczące w opisywanym przez Schulza „karnawale na opak” poddane zostają reifikacji, porównane do „kołatek” i „dziadków do orzechów". Ich ciałom towarzyszy nieustannie obecny żywioł parodii, kwestionujący ustalone zasady dotyczące rzeczywistości. Tłum ulega pod wpływem gniewu Jakuba stopniowemu rozproszeniu i niewytłumaczalnemu „zanikowi”, oznaczającemu zarazem schyłek „karnawału”:

Stopniowo jednak, znudzony błaznowaniem, wesoły ten ludek rozpraszał się w dalszych okolicach krajobrazu i tam powoli gubił się wśród skalnych załomów i dolin. Prawdopodobnie jeden po drugim zapadały się te wesołki gdzieś w szczeliny i fałdy terenu, jak dzieci zmęczone zabawą po kątach i zakamarkach mieszkania w noc balowa (NW 108).

Opowiadanie kończy ponowne pojawienie się na niebie hodowanych wcześniej przez Jakuba ptaków. Ojciec obserwuje ich wyłanianie się z horyzontu:

I wtem zaroiło się niebo jakąś kolorową wysepką, osypało się falującymi plamami, które rosły, dojrzewały i wnet napełniły przestworze dziwnym ludem ptaków krążących i kołujących w wielkich krzyżujących się spiralach. [...] Niektóre z nich, jak ogromne bociany, płynęły nieruchomo na spokojnie rozpostartych skrzydłach, inne, podobne do kolorowych pióropuszów, do barbarzyńskich trofeów, trzepotały ciężko i niezgrabnie, ażeby utrzymać się na falach ciepłej aury; inne wreszcie, nieudolne konglomeraty skrzydeł, potężnych nóg i oskubanych szyi, przypominały źle wypchane sępy i kondory, z których wysypują się trociny ( $N W$ 109).

Różnorodne gatunki opisywane są poprzez strategię reifikacji; porównania do „barbarzyńskich trofeów”. Równocześnie, stanowią one element obecnej w całym opowiadaniu „wybrakowanej”, „wadliwej” materii; w nieudolny sposób imitującej rzeczywistość, podobnie, jak „źle wypchane” sępy i kondory. Ich ciała skonstruowane sa na zasadzie groteskowego niedopasowania poszczególnych członków, określanych jako „konglomeraty”. Opis ptaków opiera się na braku i degradacji: „Były między nimi ptaki dwugłowe, ptaki wieloskrzydłe, były też i kaleki, kulejące w powietrzu jednoskrzydłym, niedołężnym lotem" (NW 109). Budzą one fascynację i obrzydzenie: określone zostają jako „[...] zdegenerowane plemię ptasie, zmarniałe wewnętrznie” (NW 110). Ich ponownemu pojawieniu się towarzyszy jednak brak możliwości porozumienia z Jakubem. Ptaki cechuje nadmierny, wynaturzony rozrost; co więcej, okazują się one ślepe:

Wystrzelone głupio wzrostem, wyogromnione niedorzecznie, były wewnątrz puste i bez życia [...]. Było to jakby muzeum wycofanych rodzajów, rupieciarnia Raju ptasiego. [...] te papierowe, ślepe ptaki nie mogły już poznać ojca. Na darmo wołał na nie dawnym zaklęciem, zapomnianą mową ptasia, nie słyszały go i nie widziały (NW 110). 
Wbrew rozpaczliwym gestom Jakuba, subiekci rzucają w ptaki kamieniami; martwe zwierzęta spadają na ziemię, przemieniając się w „dziwna fantastyczna padlinę”, która „nim doleciała do ziemi, była już bezforemna kupa pierza" (NW 110). Materia wydaje się zataczać w Nocy wielkiego sezo$n u$ prowadzacy od życia do śmierci, czerwieni do czerni krag, w którym ciała mają niepewny status ontologiczny. Jak zauważa Jan Gondowicz, w opowiadaniu Schulza ptaki „[...] potrafią przeniknąć z rejonów naśladowczych w imaginacyjny; [...] odszukać miejsce, gdzie fikcja i wyodrębniona z niej fikcja w fikcji niewidzialnie się łączą" ${ }^{26}$. Przypominają one wielogatunkowe hybrydy, przeczące zasadom biologii i łamiące reguły procesu ewolucyjnego. Ich śmierć staje się momentem groteskowej kompromitacji stworzonej przez Jakuba idei zrównania świata ludzkiego z „nie-ludzkim”: „Teraz dopiero, z bliska, mógł ojciec obserwować całą lichotę tej zubożałej generacji, całą śmieszność jej tandetnej anatomii” (NW110). Obraz martwych ptaków staje się zarazem obrazem próby nieudanej transgresji Jakuba, realizującej się zarówno pod względem biologicznym, jak i filozoficznym. Materia ptasich ciał skonstruowana jest na zasadzie przypadkowości i pozoru:

[...] były to ogromne wiechcie piór, wypchane byle jak starym ścierwem. U wielu nie można było wyróżnić głowy, gdyż pałkowata ta część ciała nie nosiła żadnych znamion duszy. Niektóre pokryte były kudłata, zlepiona sierścia, jak żubry, i śmierdziały wstrętnie. Inne przypominały garbate, łyse, zdechłe wielbłądy. Inne wreszcie były najwidoczniej z pewnego rodzaju papieru, puste w środku a świetnie kolorowe na zewnątrz $(N W 110-111)$.

Ostateczny koniec „ptasiego karnawału” Jakuba - oraz schyłek tytułowego wielkiego sezonu - oznacza zarazem powrót dotychczasowej, ustalonej kosmogonii. Siła wstrętu, kształtująca narrację opowiadania, odchodzi wraz z nadejściem dnia, zwiastującego „smutny powrót ojca”. Narracja powraca do sfery realizmu: subiekci „podnoszą się spomiędzy bali sukna i ziewają do słońca”. Adela ponownie „wstaje rano i mieli kawę”, a „kot myje się w słońcu” (NW 111). Rzeczywistość może jednak przybierać opisywaną w ten sposób formę jedynie w sposób tymczasowy. Uniwersum Sklepów cynamonowych oparte jest na nieustannej próbie przekroczenia ustalonej wizji codzienności przez nieokiełznany żywioł „rupieciarni”: podlegającej ekstatycznemu „żywiołowi transgresji” materii.

Jak zakładała w analizie relacyjnego charakteru prozy Schulza Agnieszka Dauksza, w każdorazowym akcie lektury autor Sklepów cynamonowych zawiązuje z czytelnikiem afektywna, wspólnotowa relację ${ }^{27}$. Jednym z kon-

${ }^{26}$ J. Gondowicz, Trans-Autentyk. Nie-czyste formy Brunona Schulza, Warszawa 2014, s. 202.

${ }^{27}$ A. Dauksza, Poetyka afektywna Brunona Schulza, [w:] tejże, Afektywny modernizm. Nowoczesna literatura polska $w$ interpretacji relacyjnej, Warszawa 2017, s. 71. 
struujących ją afektów jest wstręt: nieuchronnie towarzyszący wszelkim eksperymentom Jakuba, kwestionujący ustalony paradygmat antropocentryczny. Wywiera on wpływ na cielesność postaci, symbolikę barw i przedmiotów oraz procesy metamorfoz. Wszystkie wymiary awersji łączy modernistyczna świadomość istnienia niepoznanej „podszewki” rzeczywistości, wymykającej się jednoznacznej kwalifikacji. Literatura staje się przez to sposobem wyrażenia wszystkich możliwych form istnienia: objawiającego się w pełni swoich możliwości, ale także podlegającego deformacji i destrukcji. Afektywny wymiar wstrętu widoczny w obecnych w tekście „napięciach”, staje się narzędziem konstruowania narracji i tożsamości bohaterów, łącząc w sobie komizm i powagę, grozę i fascynację.

\section{BIBLIOGRAFIA}

Ahmed S., Performatywność obrzydzenia, przeł. A. Barcz, „Teksty Drugie” 2014, 1.

Bachtin M., Problemy poetyki Dostojewskiego, przeł. N. Modzelewska, Warszawa 1970. Benjamin W., Pasaże, przeł. I. Kania, Kraków 2010.

Bocheński T., Czarny humor w twórczości Witkacego, Gombrowicza, Schulza. Lata trzydzieste, Kraków 2005.

Czytanie Schulza. Materiaty międzynarodowej sesji naukowej Bruno Schulz-w stulecie urodzin i w pięćdziesięciolecie śmierci, red. J. Jarzębski, Kraków 1999.

Dauksza A., Poetyka afektywna Brunona Schulza, [w:] tejże, Afektywny modernizm. Nowoczesna literatura polska w interpretacji relacyjnej, Warszawa 2017.

Douglas M., Czystość i zmaza, przeł. M. Bucholc, Warszawa 2010.

Gondowicz J., Trans-Autentyk. Nie-czyste formy Brunona Schulza, Warszawa 2014.

Jarzębski J., Prowincja centrum. Przypisy do Schulza, Kraków 2005.

Jarzębski J., Schulz, Wrocław 1999.

Kristeva J., Potęga obrzydzenia. Esej o wstręcie, przeł. M. Falski, Kraków 2007.

Markowski M.P., Powszechna rozwiazłość. Schulz, egzystencja, literatura, Kraków 2012. Menninghaus W., Wstręt. Teoria i historia, przeł. G. Sowiński, Kraków 2008.

Nalewajk Ż., W stronę perspektywizmu. Problematyka cielesności w prozie Witolda Gombrowicza i Brunona Schulza. Prolegomena, Gdańsk 2010.

Nuda w kulturze, red. P. Czapliński, P. Śliwiński, Poznań 1999.

Olchanowski T., Jungowska interpretacja mitu ojca $w$ prozie Brunona Schulza, Białystok 2001.

Schulz B., Opowiadania. Wybór esejów i listów, red. J. Jarzębski, Kraków-Wrocław 1998.

Schulz. Przewodnik „Krytyki Politycznej”, Warszawa 2012.

Stownik schulzowski, red. W. Bolecki, J. Jarzębski, S. Rosiek, Gdańsk 2006.

Stala K., Na marginesach rzeczywistości: o paradoksach przedstawiania $w$ twórczości Brunona Schulza, Warszawa 1995. 
